\title{
釀造研究
}

昭 和 27 年 度

\section{釀造別䴯菌の Diastase}

\section{麴の研究 (VIII) 特に A.tamari group の Diastase に就て}

村上英也, 内堀信吾, 渡辺恒治, 山崎慶一

(昭和 27 年 4 月 30 日受理)

澱粉の酵素分解の而から糸状菌 Diastase が研究されるようになつて嘗て説明することの困難であつた酵 素利用 (礭造) 上のいろいろの問題が合理的に解勫され，その進歩は更に停る所を知らない状態であるが我

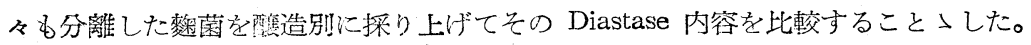

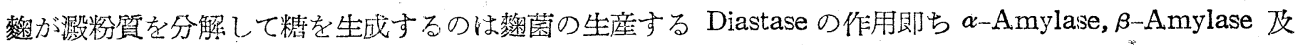
び Maltase という性質の異つた 3 種の酵素の基同作用によるものであるからその状態は之等酵素の含有量 によつて異るのみでなくその配合組合せによつて簧ることは当然である。啭粉の化学に関しては未知の所が 多いが大体最少の場合で24〜30個の $\alpha$-glucose が $\alpha$ 型に連らなり, その 2 個每に $\alpha$-Maltose となつて結合 したもの（澱粉は Fehling 液を還元しない点より closed ring を為すという）でその分解過程を知るのに最 む便利な方法はヨードによる呈色反応である。Glucose の数による呈色の変化は glucose 敛の分枝の有無に

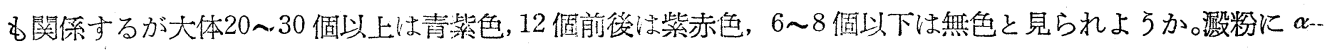
Amylaseのみが作用すると主として Glucose 6〜8 個の糊精を生じその他に Maltose と少量の Glucose を副 生しヨード反応は消失する。この際の生成物はすべて $\alpha$ 型のもので糖は Glucose として 20\%, Maltose とし て 40\% 位で飽和し之以上は進子ない。澱粉に $\beta$-Amylase のみが作用すると Maltose 単位に切断されるが いわゆる Limit Dextrine を残して飽和しこの時の鈢の生戍は Maltose として60〜70\%であるがヨード反 応は遂に消失しない。この際の生成物はすべて $\beta$ 型のもので， $\alpha$ 型の激粉からどうして $\beta$ 型のものが得ら れるがついてはいるいろの説もあるが Maltose 鎖の切れ口の $\alpha$-Glucose が mutarotation して $\beta$-Maltose を生じていると解すればよく，因みに Maltose は $\beta$ 型の方が安定で結晶し易いので市販品は $\beta$-Maltose 即 ち $\beta$-glucose-4- $\alpha$-glucoside である。 $\beta$-Amylase は糖としては Maltose のみを生成するるのとされている が多くの人が Glucose をも生成する亨を認めて Glucogenic enzyme system を想定し北原覚雄氏(1) は黒 楸菌の Diastase が $a$-Amylase 攻び Maltase を抹殺しても著量の Glucose を生ずるとしこのような性 質の酵素に $\gamma$-Amylase と命名している。 Maltase は $\alpha$-glucosidase であつて Maltose 妾分解して 2 分子 の Glucose とする作用のみをもつが $\beta$-Amylase と共に澱粉に作用するとヨード反応は消失しないお 糖 は Glucose として 60\% Maltose と.して $120 \%$ 位も生成する。

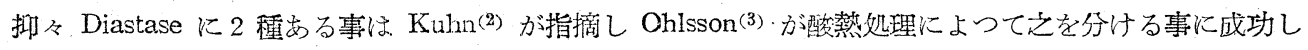

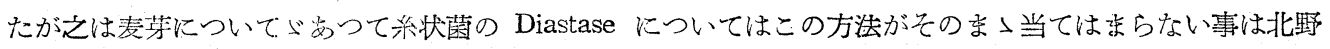
的(4) 徳岡氏(5) の認めた所で北原氏(6) が之を追試し系状菌の Diastase は耐熱性は麦芽に比べて弱く耐酸性 は $\alpha$-Amylase は弱く $\beta$-Amylase 攻び Maltase は強い事が明らかとなり，この性質からいろいろの糸状 菌の Diastase の内谷汅ついて比挍研究され首題の研究は更に一段と進歩した。即ち北原氏(7)によれば一跑

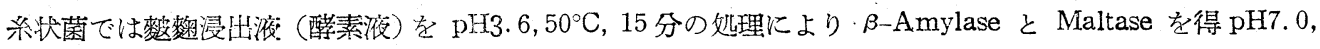

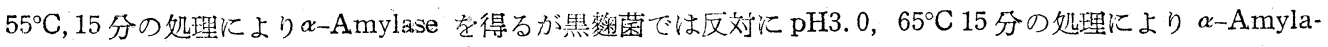
se を得 $\mathrm{pH} 7.5,60^{\circ} \mathrm{C}, 15$ 分の姏理によって殆ど Maltase を含まない $\beta$-Amylase を得且 Maltase は却つて $\alpha$-Amylase と行動を共沉し且この $\beta$-A.mylase が著量の Glucose を生ずる所から之を $\gamma$-Anylase と唱兄, 岡 崎氏 ${ }^{(8)}$ は多数の釆状菌を用いて $\mathrm{pH} 2.5,40^{\circ} \mathrm{C}, 30$ 分の処理を行い之に刘与る抵㧤性から糸状菌 Diastase は 
すべて 5 つの型に分類する事が出来る事を示し, 更に(9) その代表菌㮐を用いて梼類の分別定量を行つて試

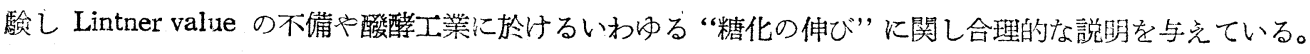

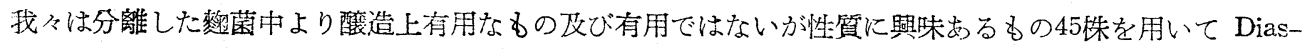

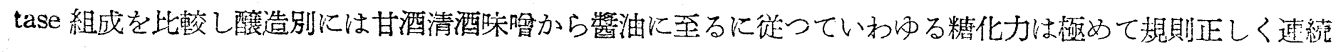
的に減退するがその減少は $\alpha$-Amylase， $\beta$-Amylase 改び Maltase の含有量が比較的規則正しく減少する

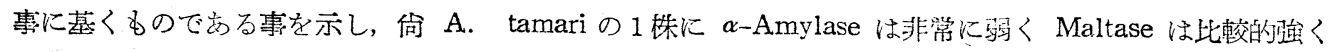

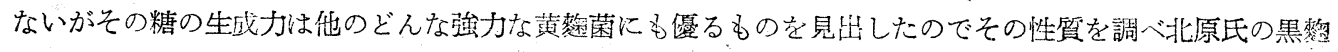

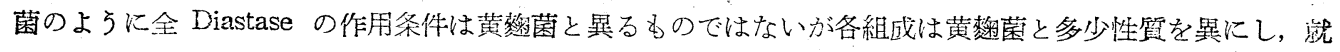
中 $\mathrm{pH} 2.540^{\circ} \mathrm{C} 30$ 分の酸爇処理によつて $\alpha$-Amylase 攻び Maltase を抹殺して澱粉より著量の Glucose を生成する事を明らかにし，佮 Lintner value，Wohlgemuth value に対する関係について考察した。

\section{実 驗}

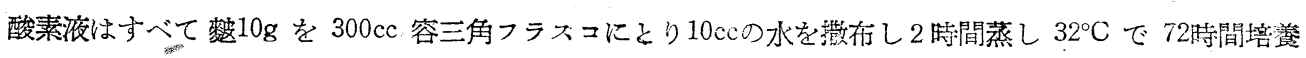

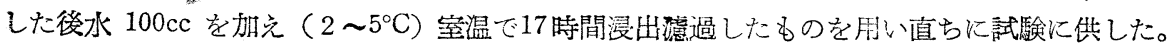

\section{A, 醇造别整菌の澱粉糖化狀況の比較}

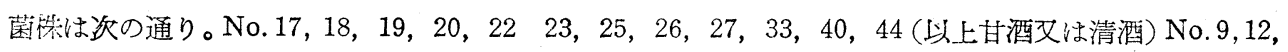
$14,15,30,31,35,36,48,39,43,57$ (以上味譄) No.11, 28, 34, 37, 41, 54, 55, 56, 57, (以上觜

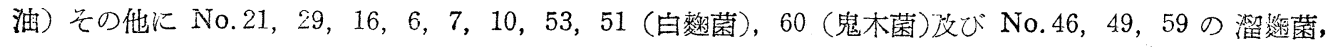
, 比較に黒楼菌 (A. usami) 計 46 蛛。

作用液配合は次の通り。

Amylase 用……醉素夜 $5 c c+2 \%$ 可溶性澱粉液 $50 \mathrm{cc}+\mathrm{Mc}$ Ilvaine 湲衙液 (pH4.8) $20 \mathrm{cc}++$ 水 $25 \mathrm{cc}$ ， Maltase 用 ……酸素液 $5 c c+2 \%$ 麦茅糖液 $20 c c+M c$ Ilvaine 緩衝液 (pH4.8) $10 \mathrm{cc}+$ 水 $15 \mathrm{cc}$,

$200 \mathrm{cc}$ 容共桎瓶に入れ $40^{\circ} \mathrm{C}$ 恒温浴榑に浸し内容温度 $40^{\circ} \mathrm{C}$ に達してから酵素液を加え 30 分每にその $2 \mathrm{cc}$ を 啋り $0.05 \mathrm{~N} \mathrm{Na}_{2} \mathrm{~S}_{2} \mathrm{O}_{3}$ 液で滴定し, ヨード反応は作用液の 1 滴を予め水 $1 \mathrm{cc}$ 大れた試験管沈滴下し 0.1 $\mathrm{N} \mathrm{J}_{2}$ 液 1 滴を加えて調べる。滴定は作用開始してから 6 時間で打切つた。この結果を醸造別にまとめると 次の通りで極めて遼続的に变化する事が知られ各醮造に於汁る菌侏の糖化曲線の上限と下限とを図示寸ると 第 1 図のよ5になりその境界に於て若干重複しつ、醬油味嚕から清酒甘酒に至るに従つて曲線は上方に向つ

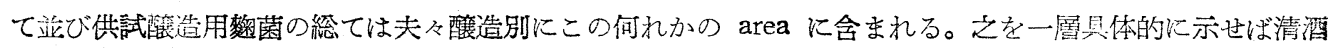

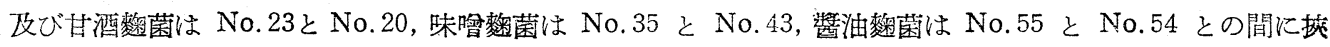
まれ夫々 No. 20 と No. 35, No.43 と No.55 は各 area に於て重複している。 Maltase 曲線についてる 第 2 図のよ弓に略同様の事が云われる。今之等の数値を表示すれば次の通りである。但し糖化率とは $2 \%$ 可 溶性澱粉液中の Total glucose (酸分解によつて定量するにその50cc 中に $1.0320 \mathrm{~g}$ glucose を含む)に対す る生成 Glucỏse の\%で見掛けの糖化率である。又 Maltase は作用 6 時間後の $0.05 \mathrm{~N} \mathrm{Na}_{2} \mathrm{~S}_{2} \mathrm{O}_{3}$ 消翼量に よりその最も多いるのを 100 として仮りに比較した数值である。

\begin{tabular}{|c|c|c|c|c|c|}
\hline & $\begin{array}{l}\text { ヨード厉広消失に } \\
\text { 要する時間 (分) }\end{array}$ & $\begin{array}{l}\text { ヨード反応消 } \\
\text { 失時の綕化摔 }\end{array}$ & $\begin{array}{l}\text { 終極 } \\
\text { Glucoseと } し て\end{array}$ & 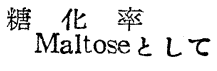 & Maltase \\
\hline 甘酒清酒 & $2 \sim 5$ & $12 \sim 15$ & $50 \sim 57$ & $94 \sim 110$ & $80 \sim 100$ \\
\hline 味管 & 䛔 $(6 〜 20)$ 多くは9〜15 & $15 \sim 17$ & $44 \sim 50$ & $84 \sim 94$ & $40 \sim 75$ \\
\hline 獎 & 妯 $20 \sim 30$ (90以上马可り) & $16 \sim 18$ & $26 \sim 43$ & $50 \sim 83$ & $15 \sim 40$ \\
\hline
\end{tabular}

糖化率が終極で Maltose として 100\%を越えるものは No.23 (110\%) と No.26 (112\%) であるが前者

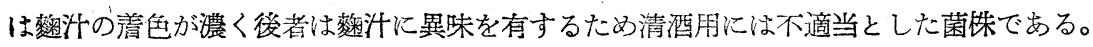

何れの醸造にも適しないとした菌(No.21)やNo.51 (白趩菌)，54 (ヒゲタK菌)，56 (西村54号菌)， 60 (鬼木菌) 等は $\alpha$-Amylase 特汇弱くヨード反応消失に 40 210 分を要し, 終極の糖化率も Glucose 之 して 28〜30\% (No.21, 51 はや>多く40\%) で甚た小い。)Maltase は No.24, 28, 37 等は微弱で No. 54, 56 等は殆ど之を欠くが No. 60 吕比較的強い（全体の菌侏から見れば間題にならないが）。No, 48 の糖化曲 線は以上の菌侏の area から離れ最上位にあるが之については後記する。

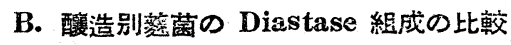

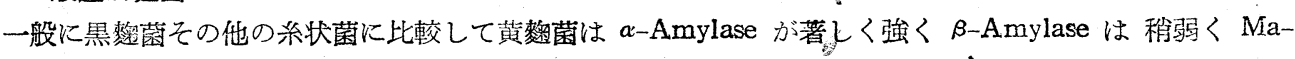
Itase は著しく弱いとされているが, 同じく葓整菌同志では個々の菌株について多少の 偏差を無視すればこ の三つの酵素は醇造別に略々一定の割合でその含有比率を变化すると見られ，従つてすべて A. oryzae type 

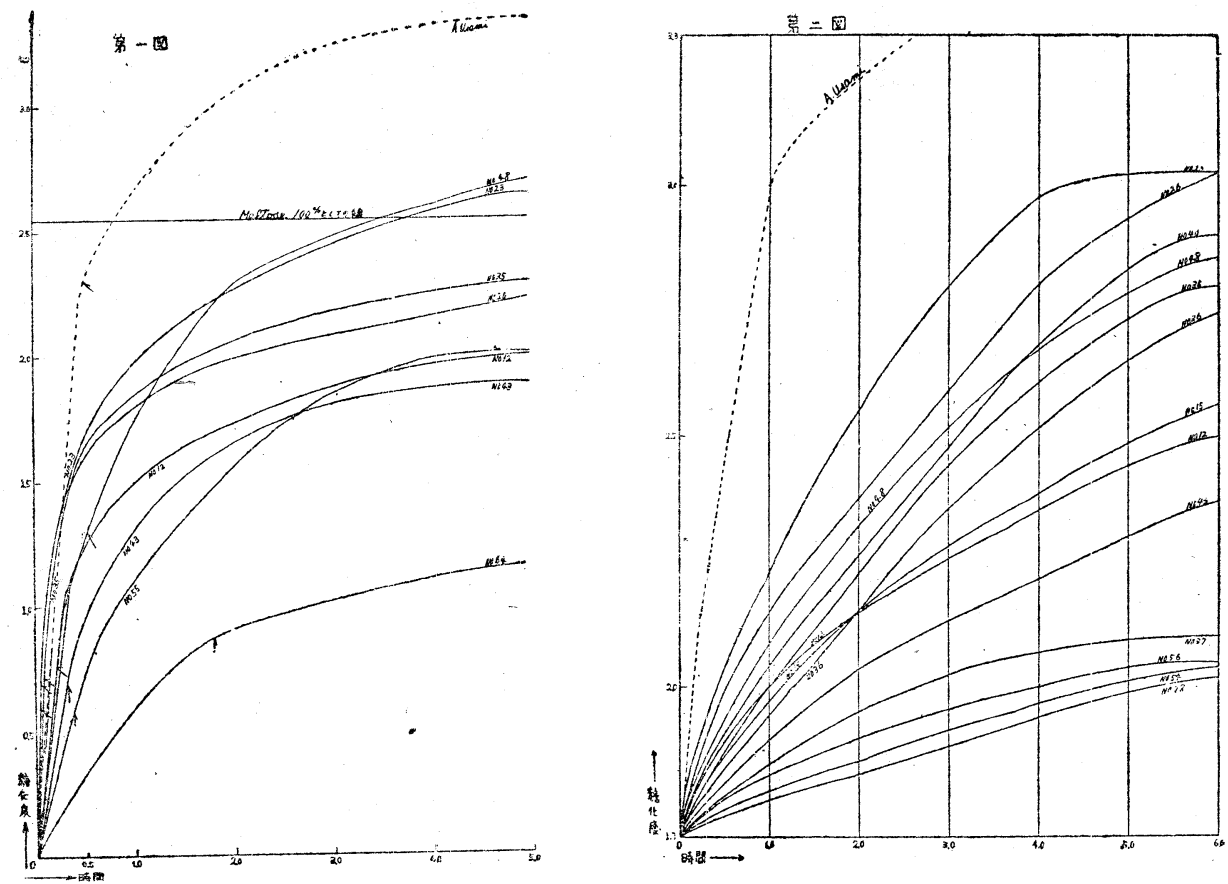

(矢印将ヨード反忘の消失点)

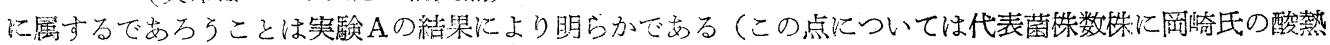

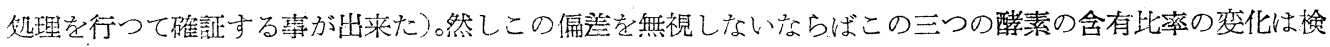

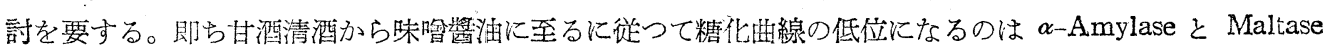

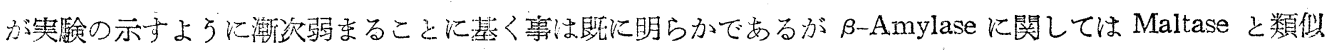

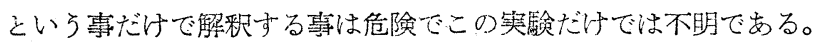

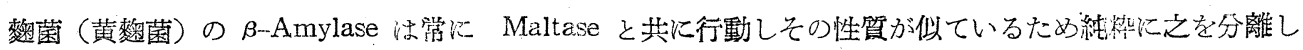

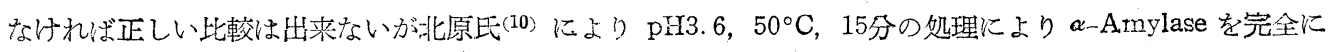

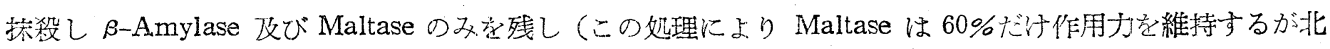
原氏は徳岡氏の Maltase は $\beta$-Amylase とその性質が全く似ているとの説を用いて $100 \%$ 作用力を維持する と教えた）この䣼素液を種々に稀釈して麦芽楉液に作用させ Maltase の全く等しい酵素液を造り之を同じ条

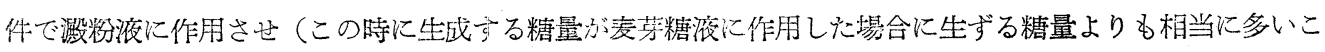

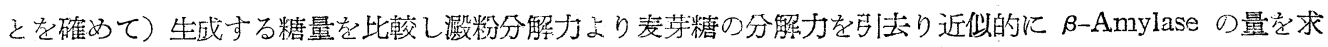
めることが出来る。勿論このため汇は民の云われるように Maltase 曲線が $\beta$-Amylase の示す曲線によく類

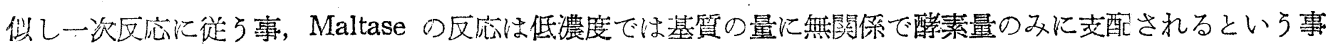
が条件となる。

䤑造別に代表菌侏としてNo.27，40，30 攻び 56 の 4 诛を選び之に上記の酸熱処理を行い $\boldsymbol{\alpha}$-Amylase を

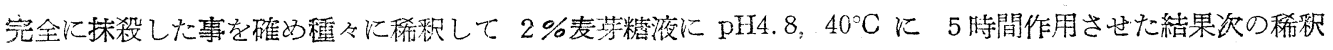
陵の場合に等 Maltase である事定知つた。

\begin{tabular}{|c|c|c|c|c|c|}
\hline 株 & & 27 & 30 & 40 & 56 \\
\hline 酸熟処理醮素液 & $\mathrm{cc}$ & 6.25 & 9.60 & 1.22 & 24.21 \\
\hline 蒸 溜 水 & $\mathrm{cc}$ & 13.75 & 10.40 & 18.78 & 0 \\
\hline
\end{tabular}

よつてこの酵素液 $5 \mathrm{cc}$ (No. 56 は $6.05 \mathrm{cc}$ )を $2 \%$ 可溶性瀑粉液 $25 \mathrm{cc}+\mathrm{Mc}$ Ilvaine 緩衝液 (pH4.8) $10 \mathrm{cc}+$

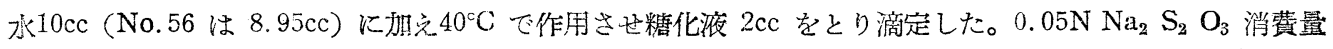
(cc) は次の通りである。

\begin{tabular}{|c|c|c|c|c|c|c|c|c|}
\hline & 10分 & 30分 & 1 時間 & 211 & $3 "$ & $4 \prime$ & 5 & $\begin{array}{l}\text { Maltase } \\
\text { 実驗Aの值) }\end{array}$ \\
\hline No. 27 & 0.18 & 0.20 & 0.30 & 0.35 & 0.41 & 0.44 & 0.47 & \\
\hline 30 & 0.10 & 0.20 & 0.33 & 0.39 & 0.42 & 0.44 & 0.47 & 0.75 \\
\hline 40 & 0.10 & 0.12 & 0.28 & 0.32 & 0.39 & 0.42 & 0.45 & 1.10 \\
\hline 56 & 0.16 & 0.18 & 0.29 & 0.31 & 0.38 & 0.43 & 0.45 & 0.20 \\
\hline
\end{tabular}


この試験は数回反覆しその都度多少の狂いは女るが全体としては上の此較值の通りであり, 各菌侏基殆ど

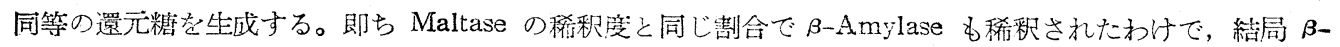

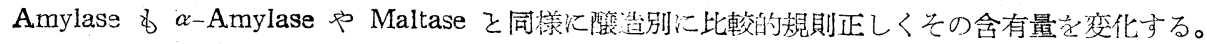

\section{A.tamari に関する試驗}

笑験（A）に於て A.tamari の中にその糖化力が黄整菌で最高の No. 23，26 に吃敵するものを見出した ので面に同一試験を反覆したところ常に之等よりも優る事を知つたので他の溜遥菌と共に比較することつし～ た。岡崎氏は多数の菌株の Diastase について比較した際 A.tamari, A. ochraceus, A. candidus 等もすべ て A. oryzae type に属寸る事を認め後二者については我々の実験も之を証明したが，我々の得た A. tamari

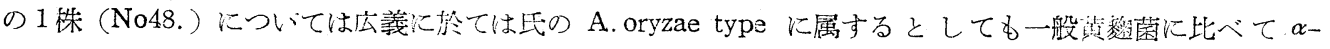

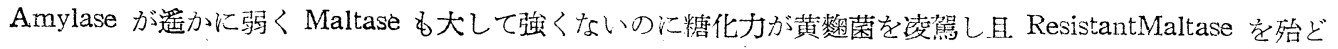

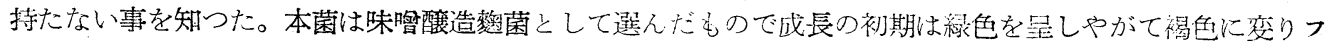
ラスコ内で典趜する際は器底の各部に往々緑色の見られる程類である。

(a) A. tamari groupの糖化曲線

笑験方法はすべて (A) と同じ。

\begin{tabular}{|c|c|c|c|c|c|c|c|c|c|c|c|c|c|c|c|c|}
\hline \multirow{2}{*}{\multicolumn{2}{|c|}{ 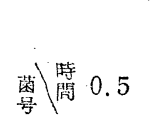 }} & \multicolumn{5}{|c|}{ Amylase } & \multirow[b]{2}{*}{6} & & \multicolumn{5}{|c|}{ Maltase } & \multicolumn{3}{|c|}{$\begin{array}{l}\text { 終極の䆂化率 } \\
\text { (作用 } \text { 时間) }\end{array}$} \\
\hline & & 1 & 2 & 3 & 4 & 5 & & 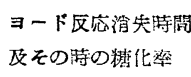 & 1 & 2 & 3 & 4 & 5 & 6 & $\begin{array}{c}\text { Glucose } \\
\text { として }\end{array}$ & $\begin{array}{c}\text { Maltose } \\
\text { として }\end{array}$ \\
\hline 46 & 0.85 & 1. 45 & 2.00 & 2.15 & 2. 30 & 2.35 & 2.40 & 35 分 $19 \%$ & $0.25 \mathrm{C}$ & 0.35 & 0.55 & 0.70 & 0.75 & 0.95 & $52 \%$ & $96 \%$ \\
\hline 48 & 1.30 & 1.75 & 2.30 & 2.50 & 2.65 & 2.70 & 2.80 & 34 分 $30 \%$ & 0.250 & 0.45 & 0.56 & 0.75 & 0.88 & 1.10 & $61 \%$ & $118 \%$ \\
\hline 49 & 0.60 & 1.15 & 1.62 & 1.95 & 2.15 & 2.23 & 2.35 & 50 分 $21 \%$ & $0.20 \mathrm{C}$ & 0.550 & 0.75 & 1.88 & 1.96 & 1.05 & $50 \%$ & $94 \%$ \\
\hline 59 & 0.72 & 1.25 & 1.70 & 2. 02 & 2.23 & 2.35 & 2.40 & 47 分 $20 \%$ & 0.25 & 0.40 & 0.50 & 0.55 & 0.70 & 0.75 & $52 \%$ & $96 \%$ \\
\hline $\begin{array}{l}\text { A. us } \\
\text { amii }\end{array}$ & 2.30 & 2.60 & 3.10 & 3.23 & 3.30 & 3. 40 & 3. 42 & 2 30分 50\% & 1.20 & 1.43 & 1.58 & 1.60 & 1.70 & 1.75 & $74 \%$ & $142 \%$ \\
\hline
\end{tabular}

之を図示すると第 3 図の通り，比較のためNo.23，51，60 及び A. usamiをも記す。

即ち A. tamari group は黄桷菌に比べて $\alpha$-Amylase がはるか弱いが同じように $\alpha$-Amylase の弱い陎

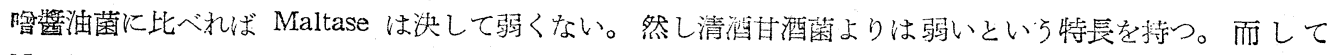

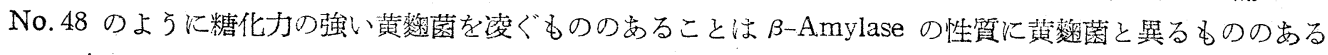
事を予想させる。

(b) 全Diastase の作用条件

\section{最適温度。}

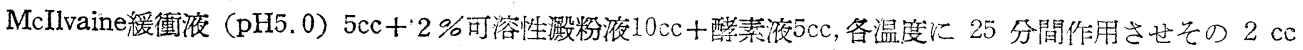
を採り滴定。

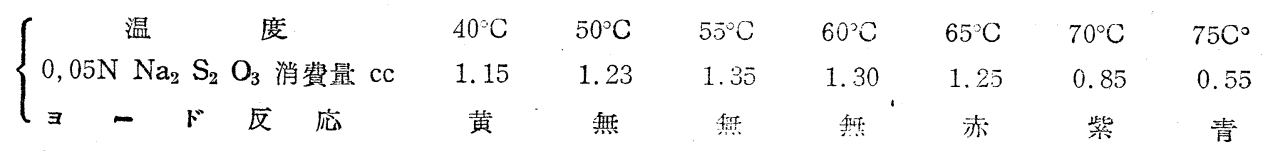

最適水素イオン濃度。

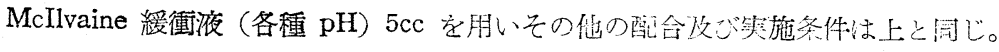

$$
\left\{\begin{array}{ccccccccccccc}
\mathrm{pH} & 3.0 & 3.4 & 3.6 & 3.8 & 4.2 & 4.4 & 4.6 & 4.8 & 5.0 & 5.2 & 5.4 & 6.0 \\
0,05 \mathrm{~N} \mathrm{Na}_{2} \mathrm{~S}_{2} \mathrm{O}_{3} \mathrm{cc} & 0.73 & 0.95 & 0.98 & 1.05 & 1.10 & 1.15 & 1.20 & 1.25 & 1.30 & 1.30 & 1.25 & 1.15
\end{array}\right.
$$

そにより最適温度は $55 \sim 60^{\circ} \mathrm{C}$ 最適 $\mathrm{pH}$ は 5.0 ～5.2 で一般黄魏菌と变りない事を知る。

\section{(c) 酸熱処理による試験}

前記したように北原氏は一般系状菌と黒剓菌の比較に於て一般系状菌では $\mathrm{pH} 3.6,50^{\circ} \mathrm{C}, 15$ 分の処理によ

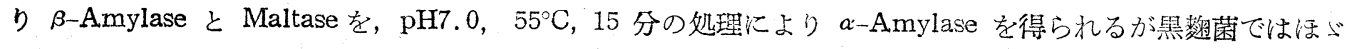

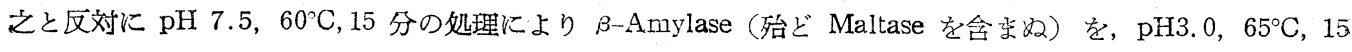
分の处理により $\alpha$-Amylase を得且黒麴菌では Maltase は却つて $\alpha$-Amylase と行動を共にするとし, 又网 畸记は $\mathrm{pH} 2.540^{\circ} \mathrm{C}, 30$ 分の処理によりその抵抗性から系状菌の Diastase を5つの型に分類したのである がを等に準じて A.tamari の 1 株にて各種の酸熱処理を行つてみた。

酵素液処理法

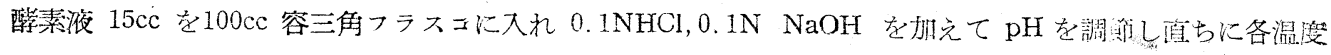


の恒湢浴槽中に時々振りながら所定時間漫した後とり上げて冷水で急冷し直ちに $M / 5$ 筑二燐酸りーダ 液又 は M/10 クエン酸を滴下してpH 5 〜 6 亿戻し適量の水を加えて何れも20ccに充す。

作用液

総て实験 (A) の配合によるが酵素液は 2 倍量使用しその代り添加蒸溜水を堌量に相当する分だけ減じ $40^{\circ} \mathrm{C}$ で作用させ，経時的沉のの $2 \mathrm{cc}$ を採り $0.05 \mathrm{~N} \mathrm{Na}_{2} \mathrm{~S}_{2} \mathrm{O}_{3}$ にて 滴定する。

その結果は次の通りである。

Amylase

Maltase

$\exists$ ヨド反応消

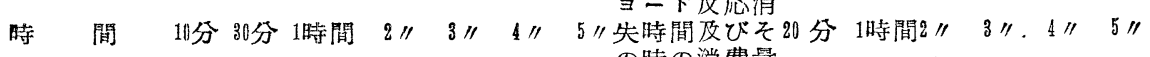
の時の消費最

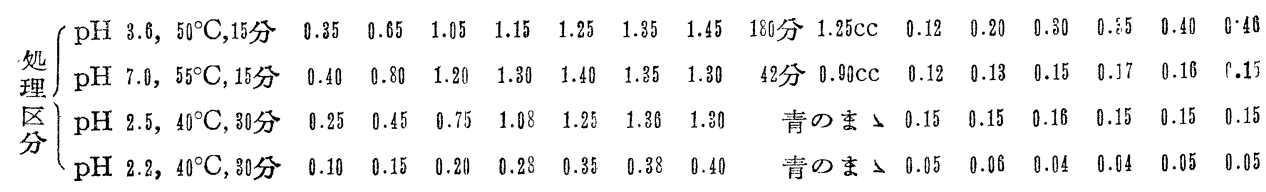

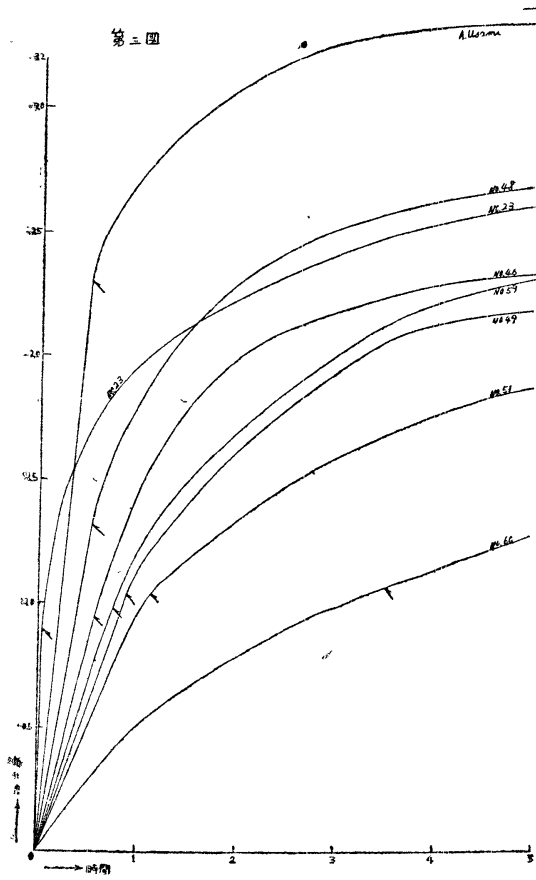

作用液中 Glucose z Maltose の分別。

ヨード法によつて与えられる糖量は Glucose, Maltose の 外総ての還元性特晢をも念它から之等を分別しなければなら ない。北原氏は Tauber \& Kleiner(11) の方法を，岡崎氏は パン醁纬の酸醋力を利用寸る Somogyi の方法を用いている が，我々は Barfoedにより中性醋酸銅溶液が $0.0005 \mathrm{~g}$ の Glucose により還元されるが Maltose では $0.02 \mathrm{~g}$ ( $1 \mathrm{c}^{\mathrm{c}}$ 中) でも邆元されない性質を利用して $\mathrm{pH} 2.5,40^{\circ} \mathrm{C}, 30$ 分 処理 の 5 時開作角液について定量すること〉し, 佮 phenylosazone を造つて確めることつした。而して Barfoed の試薬はその 純度や調整法汇よつて感度が罢る素があるから之を検定する ため Glucose の $0.2 \%$ 水溶液（正しくは $0.2026 \%$ 一ヨード 㳙) 及び Maltose の $2 \%$ 水溶液（正しくは $1.9823 \%$ 一ベル トラン洗）を造り之に作用液との条件を同じくするため夫々 1.6〜1.7\% になるように可溶性激粉を加え試験しその $1 \mathrm{cc}$ 中 Glucose は $0.0005 \mathrm{~g}$ で就元力を示すが Maltose は $0.0150 \mathrm{~g}$ でば完全に示さない悪を確好本試験に使用し得る事を知つた。 次に作用液 1ccを採り本試薬によつて還元力を比較し䅺準液 の $1 \mathrm{cc}$ 中に $0.0020 \mathrm{~g}$ の Glucose を有するるのと等洒である 事を知り，一万作用液 1ccに就てヨード法によつて全還元糖 を定量した結果 Glucose として $0.0029 \mathrm{~g}$ Maltose゙とて 0.0058g であるから作用液中の還元糖は殆ど大部 分が Glucose であることがわかり艺を分子比で表はせば Glucose；Maltose =5：1 となる。之は Maltase

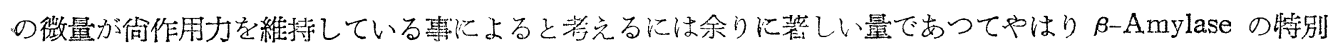
の性質に由るか又は外にこのような作用を有つ碚素が存在するとしなければならないであろう。

澱粉やその中間分解物が共存する場合の Barfoed 試薬の感度は Glucose と Maltose“の文の存在する場

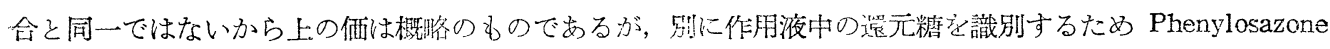
を造るにや小著量の難溶性の Glucosazone の針状結昆を生ずるのに刘しその滤液について熱水を用いて再 結しようとしても板状又は束状の Mailtosazone は得られずにこのもの Barfoed 試薬も還元しない)，結

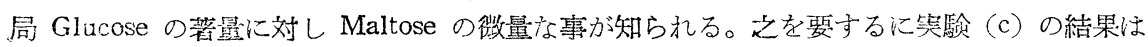

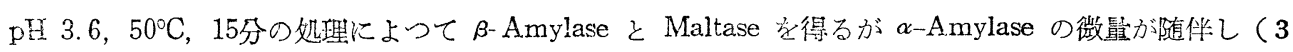

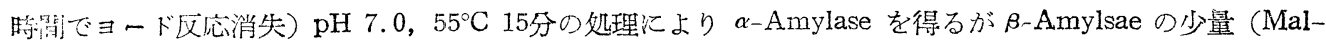

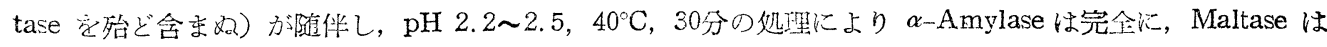

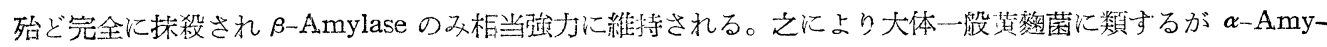

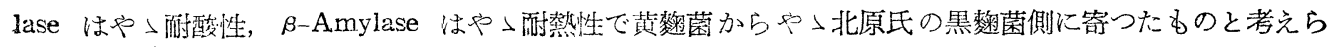
れるが Maltase は多く黄焚菌同橙 $\beta$-Amylase と行動を共にする。又岡崎氏の non-Resistant $\alpha$-Amylase 
と Resistant $\beta$-Amylase を持ち大体いわゆる A. oryzae typョに舅するが Maltase は non-resistant である。 特に $\alpha$-Amylase 改び Maltase を抹狆して澱粉液に作用して著量の Glucose を生成する事はいわゆる G! ucogenic enzyme system 或は北原氏の $\gamma$-Amylase の存在を裹書きする。

最近领塚公氏(12) 愒褐色アスベルギルス属の形態と分類関する研究発表沉於て A. tamari group とA.

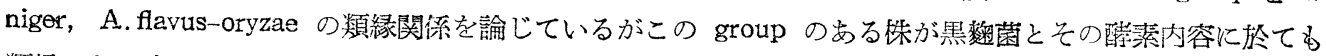

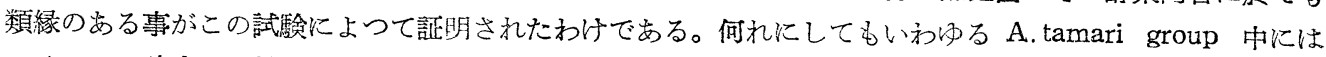

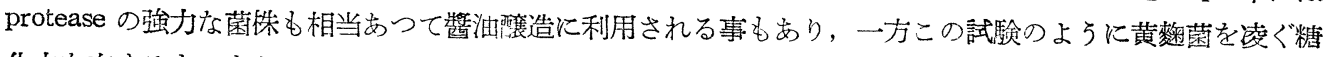

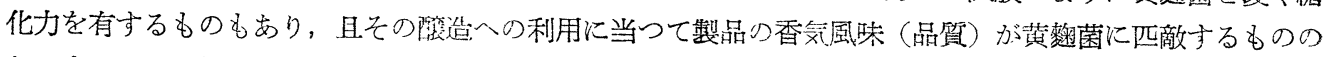
ある事はこの種の菌の研究上興味の梁い事で岁る。

(D) Wohlgemuth value, Lintner value について

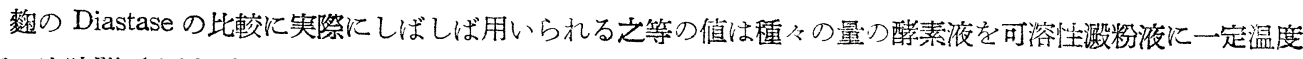
で一定時間（大陉の場合 30〜60分）分作用させてヨード反応の消失皮ざ Fehling 液の還元力を示す時の最 小の醅素液の量を表するのであるから真の Diastase の强弱を直接代示すものではなく同じような型の糖化

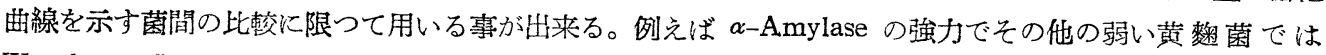
W-value は非常に大きいが L-value は小さいであろうし $\alpha$-Amylase の弱くその他の強い黒麴菌ではWvalue は小いが L-value は大きいであろ5。従つて之により直ちに黄整菌と黒棼菌の Diastase の強弱は比 較出来ない。唯このよ5な場合にむ作用温度と作用特間を適当汅することにより失用上の此較は出来る。例

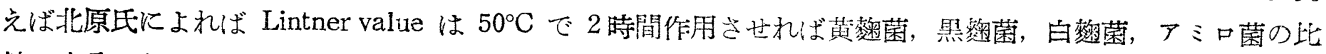

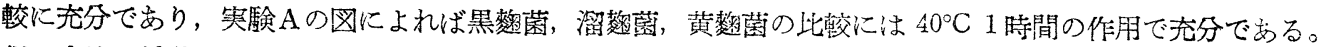

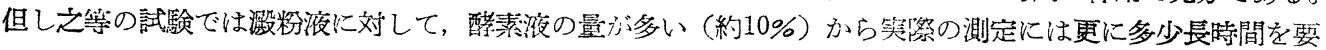
するであろう。Wohlgemuth value はョード反応消失の速さを示するのとする限り用いる事が出来るが同特 間で消失してるその時の糖化率は菌筷によつて異るのでやはり不備である。例えば岡崎氏によればヨード方 底消失時の糖化率は Aoryzae 型文 A. arramori 型 20〜30\% A. usami 型 45〜60\% Rhizopus tonkinensis 型及 Rhizopus Péka 型 50〜60\%である。このよ5に W-value や L-value はいろいろの点で不備がある が参考に次のようにして測つた之等の值と㐿験（A）の結果とを刘比する。

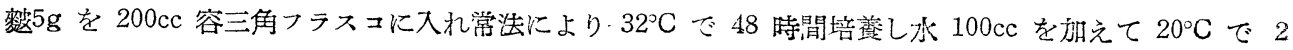
時閒浸出し醉素液とする。W-value は $0.1 \%$ 可溶性激粉液 $5 \mathrm{cc}$ に適量の酵素液を加へ $20^{\circ} \mathrm{C}$ に 1 時間静 置の後 $0.1 \mathrm{~N} \mathrm{~J}_{2}$ 液 1 滴を滴下して測定し, 本醭素液 $0.1 \mathrm{cc}$ のときの䤃素力を 1000 として表わす。

L-value は $2 \%$ 可溶性測㸮液 $2.5 \mathrm{cc}$ に適量の酵素夜を加へ $50^{\circ} \mathrm{C}$ に 1 時閒の後 Fehling 液を加えて測定 し，本酵素液 $1 \mathrm{cc}$ のときの䤃素力を 100 として表わす。

测定值 Wohlgemuth value Lintner value 100以市 $100 \sim 2.90$ 200以上 200以下 $200 \sim 400$ 400 6003000 900 900以上

摘麗

\begin{tabular}{|c|c|c|c|c|c|c|c|}
\hline $\begin{array}{c}\text { 甘酒及清酒 } \\
\text { (12株) }\end{array}$ & 1 & 10 & 1 & 0 & C & $\mathrm{i}$ & 3 \\
\hline${ }_{(11 \text { 株) }}^{\text {噌 }}$ & 7 & 3 & 1 & 1 & 4 & 4 & 1 \\
\hline 繁 $(9 \text { 株 })^{\text {油 }}$ & 6 & 2 & 1 & 4 & 4 & 1 & 0 \\
\hline
\end{tabular}

糖化曲線 No. 23 z No. 20 の閒に含をれ

る菌株 $(17,18,19$, $20,22,23,25,26,27$, $33,40,44)$ 同No. 35 z No. 43 の 間飞含玉れる菌株 $(9,12,14,15,30,31$, $35,36,39,43,57)$ 同 No. 55 そ No. 540 間に含まれる菌株 $(11,28,34,37,39$, $43,54,55,56)$

その他主な菌铢の值は次の通りである。

$\left\{\begin{array}{crrrrrrr}\text { 菌 号 } & 46 & 47 & 48 & 49 & 51 & 59 & 60 \\ \text { Wohlgemuth value } & 130 & 220 & 110 & 130 & 160 & 250 & 130 \\ \text { Lintner value. } & 180 & 210 & 200 & 100 & 50 & 150 & 50\end{array}\right.$

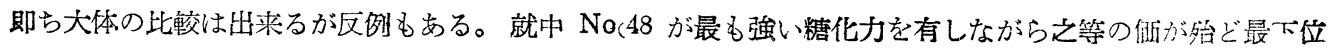
に属するのは上記の理由による。 


\section{要 旨}

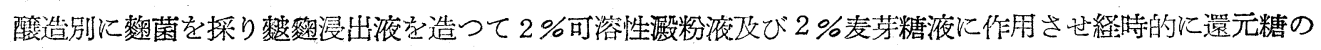
生成を定量して糖化曲線を描き且岡崎氏の酸熱拠理を行つて之等はすべていわ沛る A. oryzae type に属す

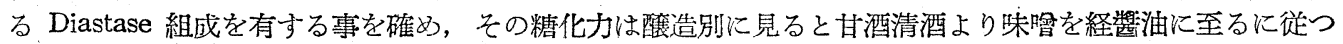
て極めて順序正しく弱くなるがその理由は $\alpha$-Amylase, $\beta$-Amylase 及び Maltase が共に減少する事に帰せ られる。

次に A.tamari の中に黄㴔菌に比べて $\alpha$-Amylase が著しく弱く Maltase は大して強くないがその見掛 の糖化率が之を倰ぐものを見出したのでその 4 怢について比較した結果すべてにこのような性質のあるあの ではないが，一般に A.tamari group は黄霜菌に比べ $\alpha$-Amylase は著しく少いがその割合に Maltase と $\beta$-Amylase を有しかなりの糖化力を示す事を知り，その強力な 1 株について種々の試験を行つた。即ちそ の全 Diastase の作用条件は一般黄粷菌と同じであるが䤃素液を酸熱処理して各組成部の性質を比較すると 一般に比べ $\alpha$-Amylase はや>耐酸性で $\beta$-Amylase はや〉耐熱性であるが Maltase は多く $\beta$-Amylase

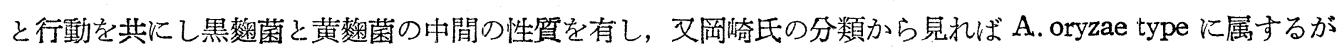
Maltase が non-resistant であり，又 $a$-Amylase 攻び Maltase を抹殺した酵素液を澱粉液に作用せると直 接著量の Glucose を生成する事を認めいわゆる Glucogenic enzyme system 或は $\gamma$-Amylase の存在を証 明した。

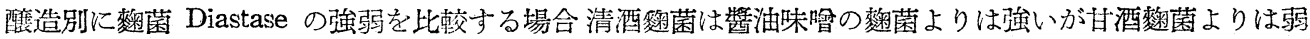

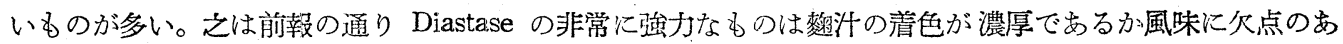
るものが多いために我々が清酒麴菌より除外したのであるが，この事は既に大谷義夫博士も明らかにされた

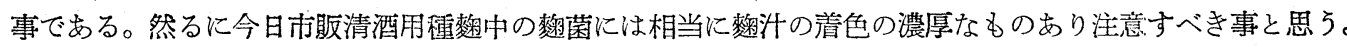

（註）本試験を終るに当り岡崎浩氏は最近の日本農芸化学会誌上で糸状菌の Amylase と植物性の Amylase (麦芽)との比較に於て特に糸状菌の $\beta$-Amylase が Glucose を生成する力を有するとし之を $\beta$-Amylase と称している。 終りに種名御注意を賜つた松本，山田両先生に感謝する。

交

献

1) 北原, 福井: 醴工学, 27, 254-257 (昭24).

2) Kuhn : Ann. 443, 1 (1925). $\quad$ 3) Ohlsson : Z.Physiol Chem. 189, 57 (1930).

4) 北野: 工化, 38, 1049 (昭10).

6) 北原, 久留島: 醱工学, $27,1-5$ (昭24).

7) 北原, 久留島: 釀工学, 27, 213-217 (昭24).

8) 阔崎：農化, 24, 88-96 (昭25).

9）岡崎：農化，24，201-214（昭25）

10) 北原, 久留島：醴工学, $27,6-12$ (昭 24$)$.

11) Tauber \& Kleiner: J. Biol. Chem. 99, 249 (1932),

12）飯塚：昭和 27 年 4 月 4 日 日本農芸化学大会講演

\section{Studies on Koji (VIII)}

Comparative researches on diastase of koji for various kinds of brewing. On the diastase of A.tamari group

By

H. Murakami, S.Uchihori T. Watanabe. and K. Yamazaki

The dastatic actions of various kinds of "Aspergilli for brewing" were compared with each other by the saccharification of starch and maltose with the wheat-bran koji extract, which was treated under various. ${ }_{\text {. }}$ conditions of $\mathrm{pH}$ and heating or not treated.

The reason why diastatic activity of koji is in exactly regular decreasing order of "Amasake", "Sake", "Miso" and "Soy" depends on the successively lowered contents of $\alpha$-amylase, $\beta$-amylase and maltase.

A very strongly diastatic kind of A.spergillus was found among the A.tamari group compared with any kinds of yellow-green Aspergilli. Its conditions of total diastatic action on starch were not different from any yellow-green Aspergilli but its properties of each components of diastase were somewhat 
different, for example, its L-amylase was more or less resistant to acid and $\beta$-amylase to heating, and it had not the so-called resistant maltase. So it seemed that it had the intermediate properties between yellow-green Aspergilli and black Aspergilli.

Finally we found that it had a strongly glucogenic enzyme system or so-called $\gamma$-amylase which produces directly considerable amount of glucose from starch without action of L-Amylase or maltase.

\section{外國における醊酵學の最近の進步 (III)}

$$
\text { 川村 信 一 郎 }
$$

\section{$\S 7$, ビタミン}

\section{第3 章 榮楸品, 抗生物翼など}

徽生物により酸醄法でビタミンを造る工業が近頃注目されて来た。経済的に造られるものとしてはビタミ ン $\mathrm{B}_{2}$ (リボフラビン) が最す大切で, 日本でも研究され工業化されている。次にビタミン $\mathrm{B}_{12}$ が数種の放線 状菌や細菌によつて造られる。これと密接な関倸のあるものとして APF (動物蛋白因子)がある。またビタ ミン Dの母体であるエルゴステロールが数種の酵母やが゙によつて造られる。ビタミン $\mathrm{B}_{1}$ (チアミン) に富 む酵母については 8 で述べる。

(1) ビタミン $\mathrm{B}_{2}$ (リボフラビン)

徵生物を利用してビタミン $\mathrm{B}_{2}$ そのものや $\mathrm{B}_{2}$ に富む製品を得ることは戦前から注目され，大戦中に日本 でるとりあげられ，さらに最近ますすす実用化に進んでいる。米国では食品としては小麦粉の強化に，飼料 としては䌖用にビタミンが $\mathrm{B}_{2}$ 添加されている。醴酵法により得られるビタミン $\mathrm{B}_{2}$ 濃縮物は他のビタミン 類を含むため合成品よりる有利である場合もある。

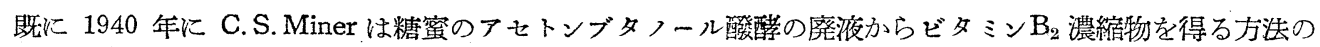
特伡 (米 $2,202,161$ )を得たが，このような製品は飼料添加料として米国市場に出ている。5 年後のM.T. Walton の特許 (米 2,368,074) ではトウモロコシと玄米とを原料として Clostridium acetobutylicum (Wei-

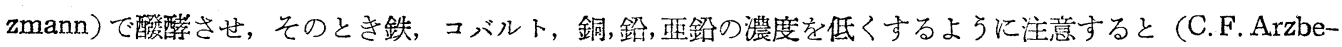
rger) (1943) 参照)，ビタミン $\mathrm{B}_{2}$ の収量がよくなるとされている。トウモロコシ鋉のアセトンブタノール 酸醉によりビタミン $\mathrm{B}_{2}$ を製造する場合鉄は有害である。 R. J. Hickey（1947）は $2_{1} 2^{1}$ ービピリヂルを酸に 加光遊離の鉄と結合させて除去寸るのに成功した。

D. A. Legg, Beesch (1945) の特訢によるとアセトンブタノール菌で米とトウモロコシとの混合物を原料 としてビタミン $\mathrm{B}_{2}$ を造るとき西䟽酸ソーダを加えると収量が増す。A. Leviton (1946)はCl.acetobutylicum によつてビタミン $\mathrm{B}_{2}$ をつくるときの阻害に対する亜硫酸塩と鉄との相互関係を説明しようとした。Leviton はこの酸酵法によるビタミン $\mathrm{B}_{2}$ の収量を上げることにつき特許 $($ 米 $2,477,812)(1949)$ を得た。即ちカダ 一ゼ又は酵母を加えると鉄がかなり存在してもビタミン $\mathrm{B}_{2}$ 生産に影響を与えなくなる。つまり䤃素により 過酸化水素が分解されるので，ビタミン $\mathrm{B}_{2}$ に対寸過酸化水素と第二鉄イオンとの破壊作用が防がれると考 光らる。

脱脂乳からカゼインを沈澱させたホエー (乳漿) もビタミン $B_{2}$ 濃縮物を造る原料として便用される $(R$. E. meade, Pollard, Rodgers (1945))。 meade ら 3 氏 (1947) はさらにこの研究を行い, Cl. acetobuty-

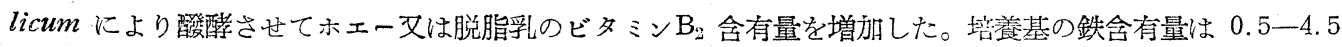
p.p.m. の範囲とした。このとき $0.1-2.0 \%$ テシローズを加觉るとビミン $\mathrm{B}_{2}$ の生産は大いに增加した。 そしてキシローズの材料としては亜硫酸パルプ廃液又は木材糖化液を予熱じたすのが適当であつた。ホエー からビタミン $B_{2}$ 濃縮物を造る特許 (Pollard, Rodgers, meade (1948)), Rodgers, Pollard, meade (1948》) があつてアンモニウム，、グネシウム，マンガンの塩類がビタミン $\mathrm{B}_{2}$ の品質に影響するとされている。

ビタミン $\mathrm{B}_{2}$ を生産する改生物として最る興味あるものに日本でも利用されている Eremothecium ashbyii (A. Guillermond (1936)) がある (J. Rudert (1945)， H.O.Piersma (1946) 参照)。

ドイツの E.Deseive (1947) は E.ashbyii によるビタミン $\mathrm{B}_{2}$ の生産について報告したが，このとき原料 をながく殺菌し過ぎると破壊される熱に不安定な因子が関係すると述べた。宸素源としてはブドウ糖がよく 窒素源としては酵母水や麦芽汁がよかつた。シスチンが不足すると徵生物の生長るビタミン $\mathrm{B}_{2}$ の生産も悪 くなる。C.Chin (1947) によれば窒素源にはペプトンがよく,グルタミン,アスパラギン,アラニン, 硫酸アンモ 